\title{
School Principals and Inclusive Schools: A Case Study of Complex Contexts and Competing Perspectives
}

\author{
Michael Fairbrother ${ }^{1}$, Kimberly Maich ${ }^{2}$, \&Steven Sider ${ }^{3}$ \\ ${ }^{1}$ University of Ottawa, Ottawa, Ontario, Canada \\ ${ }^{2}$ Memorial University, St. John's, Newfoundland, Canada \\ ${ }^{3}$ Wilfrid Laurier University, Waterloo, Ontario, Canada \\ E-mail: ssider@wlu.ca
}

Type of the Paper: Research Case Study.

Type of Review: Peer Reviewed.

Indexed In: OpenAIRE.

DOI: http://doi.org/10.5281/zenodo.3519497.

Google Scholar Citation: IJCSBE

\section{How to Cite this Paper:}

Fairbrother, Michael., Maich, Kimberly., \& Steven Sider. (2019). School Principals and Inclusive Schools: A Case Study of Complex Contexts and Competing Perspectives. International Journal of Case Studies in Business, IT, and Education (IJCSBE), 3(2), 59-67. DOI: http://doi.org/10.5281/zenodo.3519497.

International Journal of Case Studies in Business, IT and Education (IJCSBE)

A Refereed International Journal of Srinivas University, India.

IFSIJ Journal Impact Factor for 2019-20= 4.252

(C) With Authors.

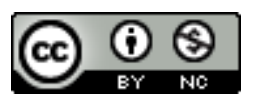

This work is licensed under a Creative Commons Attribution-Non Commercial 4.0 International License subject to proper citation to the publication source of the work.

Disclaimer: The scholarly papers as reviewed and published by the Srinivas Publications (S.P.), India are the views and opinions of their respective authors and are not the views or opinions of the S.P. The S.P. disclaims of any harm or loss caused due to the published content to any party. 


\title{
School Principals and Inclusive Schools: A Case Study of Complex Contexts and Competing Perspectives
}

\author{
Michael Fairbrother ${ }^{1}$, Kimberly Maich ${ }^{2}$, \&Steven Sider ${ }^{3}$ \\ ${ }^{1}$ University of Ottawa, Ottawa, Ontario, Canada \\ ${ }^{2}$ Memorial University, St. John's, Newfoundland, Canada \\ ${ }^{3}$ Wilfrid Laurier University, Waterloo, Ontario, Canada \\ E-mail: ssider@wlu.ca
}

\begin{abstract}
Case studies have increasingly been used in the field of Education to help school teachers and principals engage in reflection and effective practices. This case study is particularly relevant to the dilemmas encountered when supporting students with disabilities in schools. The school principal in the case, Mr. Thomas Donaldson, is committed to supporting all students in the school. Mr. Donaldson believes that students' attachment to school forms through healthy relationships built on empathy and commitment between teachers and students. Teachers require time, compassion, and professional learning opportunities to best support students with disabilities in ways that result in positive changes for everyone. Mr. Donaldson tries to approach his teachers the same way: He seeks to know and understand the diverse needs and values of his teachers and offers them his perspectives on inclusive, meaningful learning opportunities in the hope of provoking change. The case study begins with a description of the context in which the school is situated. The case then presents the perspectives of Mr. Donaldson and three new teachers before the start of the school year. These perspectives provide a backdrop to the realities principals face as they strive to generate cohesive approaches infused from inclusive ideals and guided in the realities their students live. Meeting the needs of his teachers and their students, Mr. Donaldson looks forward to cultivating a healthy inclusive school atmosphere. The case concludes with an analysis of key aspects including attachment, teacher efficacy, and inclusion.
\end{abstract}

Keywords: Principal, Professional learning, Attachment, Efficacy, Inclusion.

\section{INTRODUCTION: CASE STUDIES FOR PROFESSIONAL LEARNING IN EDUCATION :}

Case studies are helpful in gaining insight into real-world issues and dilemmas (Hackney, McMaster, \& Harris, 2003) [1]. Although case studies have been used extensively in medicine and business, they have not been as commonly incorporated in professional learning for teachers (Watson, 2014) [2]. Although this trend is changing, there is still a significant lack of case studies to support the professional learning of school principals (Griffin \& Ryan, 2018) [3].Those responsible for principals' development have found that case studies support reflective practices on ethical dilemmas (Gardiner \& Tenuto, 2015 [4]; Hanhimäki \& Tirri, 2009 [5]). Case studies are particularly effective for specific problems that principals encounter, sometimes known as a "disorienting dilemma" (Mezirow \& Taylor, 2009 [6]) or “critical incident” (Yamamoto, Gardiner, \&Tenuto, 2014 [7]).

In the case that follows, we consider a different framework from a traditional research paper. We commence by presenting the general context of the situation. We then turn to the specific situation that confronts a principal. This case specifically examines the issue of how principals can nurture inclusive school environments where all students are welcomed and supported. The case is based on a research study that the authors have been engaged with but all identifying details within the case have been changed. The case study includes an examination of considerations related to attachment, teacher efficacy, and inclusion. The case concludes with questions and resources that are provided for exploration and further professional learning. 


\section{CONTEXT OF URBANA ELEMENTARY SCHOOL AND THE NATURE OF ITS LEADER MR. DONALDSON :}

Comprised of approximately 600 students from kindergarten to grade 6, Urbana Elementary School (UES) is located in the urban heart of a large city with a population of approximately 400000 in North-eastern USA. It has a sister city across the nearest state line with a population of nearly 1000000 which is more economically prosperous. More advantaged families generally consider Urbana Elementary to be a less attractive school choice and the upper middle class urban neighbourhood that encircles UES tend not to choose it as their preferred school of choice. Students that attend UES live in less prosperous areas of the city. Theyare bussed in from as far as a tenkilometre radius.

Urban Elementary is nearing its $75^{\text {th }}$ anniversary and is led by its principal, Mr. Thomas Donaldson. With a faculty of 30 educators, nearly 600 students, and numerous adults who visit, volunteer, and take part in various services offered to families, UES is bursting at its seams. Previously under a threat of being under-populated and abandoned, this elementary school has rather unexpectedly doubled in population over the past five years. It is characterized by classes over both size and composition limits. There are insufficient numbers of books for home reading, classrooms are fully maximized, and the library has been turned into a classroom for lengthy sections of every school day.

The population burst is likely attributable to the services, affordability, and opportunities that exist for the parents and guardians of the children attending UES. Its central location, being adjacent to a larger, more affluent city across the state line makes it a short term stopping point for families working their way up the socio-economic ladder. Its proximity to housing for military families at a nearby army base, opportunities for cheaper housing within its catchment area, and its proximity to an adult education center combine to create a current of children in and out of the school throughout the year. Many of the students making up its core transitory population are children that have moved multiple times are in and out of UES as their parents come from rural communities to complete a course at the nearby adult education centre, for example, move back upon completion, then return at later dates repeating this process.

In large part, due to the challenges the teachers are facing in meeting the social, emotional and academic needs of the students at UES, there is a significant annual teacher turnover that happens yearly. Because some teachers consider the students "too unready" or "unwilling to learn," Mr. Donaldson regularly suggests that these teachers apply for transfers to less hectic schools when enough seniority has been accumulated. This results in many beginning teachers filling the school's teaching vacancies. Since many of these new teachers are female, there seems to always be quite a few teachers on maternity leave with even more beginning teachers filling these vacancies. As such, UES has a transitory population of both students and teachers and this can make it hard for Mr. Donaldson to in still the tenets he believes essential to fulfilling his vision of an inclusive, safe, healthy, and happy school.

Mr. Donaldson is a seasoned administrator. He began his career as a high school history teacher, spent seven years teaching, and was then promoted to assistant principal for another eight years. Currently, he is in his seventh year as principal of UES. After overcoming the culture shock of moving from a high school setting, he now perceives that his move into an elementary environment was his calling; a perfect fit with his educational beliefs. Equipped with a master's degree focused on child development and student engagement, Mr. Donaldson views the nature of early education as the quintessential time to provide students the security and foundations for positive lifelong learning. He sees students' social-emotional and academic success both inextricably intertwined and rooted in a healthy attachment to school in their early years of schooling. For him, it is key for teachers to focus on forming attached relationships with their students, as this solid foundation will provide students with the willingness to take on and persist with academic challenges they will face in the future.

Since many of the students do not live close to each other and are bussed in, Principal Donaldson feels that the school needed to become the natural hub that connects parents, children, and school staff. With his teachers and parent committees, there are many cultural activities as well as evening and weekend activities providing opportunities for an interplay of families and teachers to play together, celebrate together, and to learn together. These opportunities of togetherness between families and 
educators involve a lot of preparation to make them happen and involve commitment from all parties (particularly from teachers) to get involved inside and outside of classroom hours. However, he believes so passionately in the need to in still community that he tirelessly works at shedding light on the necessity that this is how authentic and positive community needs to be formed. In his perspective, when you have teachers, students, and parents working together, particularly outside of more academically-focused hours, an energy that reverberates back into the classroom is created. In the wake of this energy, students see their teachers differently, parents see the teachers differently, and most importantly, teachers see the students differently. For Mr. Donaldson, working with his teachers to help them develop their understanding of attachment and relationship development within and beyond academic spheres is the underpinning to healthy child development and student achievement.

\section{CASE NARRATIVE :}

It is August $24^{\text {th }}$, the week before students begin their school year and the first day that teachers return for professional development and to begin to set up their classrooms. Like every year for the past seven years, Principal Donaldson eagerly, yet with a bit of anxious trepidation, anticipates the start of a new school year. Locking his car and walking toward the entrance of the school, he finds himself reflecting on his first day as principal of Urbana Elementary School (UES). He recalls the apprehension he once felt as a leader of a school of young students and teachers with much more experience than him. Chasing down drug dealers and searching out truant students appealed to him much more at this moment than greeting a bus full of eager and highly energetic young learners. Close to seven years later, he chuckles at his then-perceived self-doubt as an elementary school leader. He knows he haschanged in terms of his understanding of the curriculum and core skills that students need to learn in their elementary years. However, he also sees how his own core principles as an inclusive educator have remained a consistent backbone to his leadership over the past seven years.

It is the UEA students' social and emotional needs that have always underpinned the direction Mr. Donaldson takes when considering class composition, school goals, and professional learning; this year is no different. He has a dedicated core group of teachers at UES and they share his vision in how to provide an inclusive educational environment for all of the students, taking into account their diverse and challenging backgrounds. However, he has a few faculty members that remain isolated, rather than collaborative, and he is also welcoming a group of new teachers to his school. He understands the challenges his teachers face and the rumours that some other teachers within the district spread about how many of their students are "unteachable." He does not deny that his students face more social, behavioural, and academic obstacles than many other students at many other schools, but he believes that his inclusive leadership style provides one of the ideal elements in bettering his students' academics lives—and much more.

Twelve years ago, Mr. Donaldson wrote his master's thesis on student engagement, where he sought to blend theory and knowledge to improve his understanding of why too many students in his high school were marginalized, left without the resilience to overcome negative predispositions to school and subsequently dropping out. When he transitioned into the elementary level, Thomas began sharing his perspectives and understanding of healthy child development, as well his thoughts on how to increase student engagement. This morning, as he walked through the school doors, fragments of these thoughts and experiences ran through his mind.

Mr. Donaldson's belief in working with his staff to develop their understandings of the importance of helping students be prepared for learning is at the utter core of his initial professional training. As with every year in his leadership positions, it was extremely important to him that he reiterated the necessity for the teaching staff to be united in this belief. Mr. Donaldson has recently hired three teachers: Emily, a brand-new teacher; Jennifer, a teacher with three years of experience and who was coming from another school; and Jeannine, who also had some teaching experience from a different school but who had also been exposed to the UES community through supply teaching. The three had interacted with Mr. Donaldson over the past few days and he wanted to ensure they would get the support they needed. He understood that Emily, Jeannine, and Jennifer did not have much if any, experience working with the complexity of needs they were about to confront. Just as he was overwhelmed his first day at UES just over seven years ago, he empathized with his new group of teachers. Not only was it essential for him to find ways for them to understand the balance that needs 


\section{International Journal of Case Studies in Business, IT, and Education SRINIVAS (IJCSBE), ISSN: 2581-6942, Vol. 3, No. 2, October 2019.

to exist between core academic expectations and the social and emotional needs of his students, he also needed to ensure that that they were ready for the challenges ahead. Thomas was worried at this time of year (in fact, at every time of year)that these complex needs could cause a swift burnout in his new teachers.

Mr. Donaldsonarrangeda few days at the beginning of the year to help teachers begin to feel comfortable with the challenges they were about to face in their classroom but also the rewards that would come with working with such a student body. He had seen teachers leave because they could not adapt to alleviating the anxiety and stress that inevitably comes from not being able to reach those students detached from their teachers, their classrooms, and the school. He did not want Emily, Jennifer, or Jeanine to experience such burnout, nor did he want to see them become stuck in a cycle of negativity detrimental to their professional growth as well as the needs of their students. To be inclusive as a school leader and meet the needs of students, it was essential for Mr. Donaldson to be understanding of the needs of his teachers. As the doors to the school shut behind him, he heard a car turn into the parking lot. Turning to check on who it might be, he realized he did not recognize the car, and that it must be one of his new teachers.

\subsection{Emily}

Emily recently graduated from university with a Bachelor of Education. She had been lucky enough to get some supply teaching within the school board, though not at UES. Her supply teaching had been at a few schools that were considered to be "better off" than the population UES serves. She had hoped something might come up at one of those schools but the postings at these types of schools were quickly filled by teachers in the district with high seniority points. Still, she was excited with getting a one-year temporary contract following graduation to teach grade one at UES. She had spent the summer thinking about curriculum and assessment planning, figuring out what kinds of topics she was going to teach her grade one students, and whether or not she should include phonics in her reading instruction. During her teacher training program, Emily formed an early reading belief system that she was going to bring the fun back into literacy learning. She believed her positive energy was going to carry her students towards academic success and that her students were going to take the next steps into the world of academic learning airly seamlessly. She believed she was ready! Emily had heard great things about her new principal and was excited about the prospect of doing what she had dreamed about for quite a long time. Emily arrived at her school full of eagerness, full of anticipation at meeting her professional peers, and full of trepidation at the newness of it all. Her supply teaching last year was successful and her students had loved her. She felt ready for anything. The memories of her university coursework were fading as she walked into the school, made her way down the hall towards the library where the staff meeting was going to be held and found a seat next to a more mature looking teacher. This woman, her new colleague, looked to be deep into planning a literacy lesson while she awaited the start of the meeting. Even so, with a wide and welcoming smile, Emily gently introduced herself.

\subsection{Jennifer}

Startled out of her planning by an over-eager and genuine-looking young teacher, it took Jennifer a moment to wipe the misplaced annoyance off of her face. Even with her quick turnaround in attitude and appearance, she noticed a slight crack in her new colleague's smile who had obviously noted her immediate reaction. She equally quickly realized that the woman standing above her must be Emily, the new teacher she had heard about who was fresh out of school and full of theory, idealism, and optimism. She was too late to provide a welcoming hello as Emily had turned to introduce herself to no doubt more of a collegial colleague. Jennifer felt a mere touch of guilt but counterbalanced this by reminding herself that she hoped that she would only be at this school for one short year. After that, she would hopefully have enough seniority points to get a permanent position in the affluent community just up the highway at a school where children were teachable. Jennifer had heard from other teachers at her previous schools where she had worked during her three-year career, that many of the children that attended UES were unteachable, that they did not want to learn, and that teachers were always being disrupted by students moving in and out of their classrooms. She had been told by some teachers that most of the kids never learned to read and do math properly and that though they were not diagnosed with a learning problem they probably should be. The parents had issues, too she had been told. She was coming to UES with the perception that most students' homes had single 
parents, low affluence, and were unhelpful in providing academic and social support. The grade two position she had taken was a step-up her climb to the top of the teaching placement ladder-no matter what the students were like. Some of the same teachers who had helpfully informed her about the students and families had also gossiped about the overly well-minded and enthusiastic principal Mr. Donaldson. Apparently, he "believed in unlocking the strengths inside every teacher and every student," and who tried to "sell" teachers on the foundational power of teacher-student relationships, the role of healthy child development, and how these components were central to good teaching as well as social and academic successes. Jennifer felt overwhelmed at the prospect of having to teach in a school that undervalued learning and overvalued problems that the families should be looking after ... not the schools. Inclusion means finding instructional strategies that work for your learners, she considered, but inclusion only works when the kids decide they are going to try and learn. For all that other stuff? Parents have to get better at parenting. Moments later her overly optimistic and naïve colleague sat down beside her, shifted in her seat, and it seemed to Jennifer, slide her chair a few inches towards the other teacher a few spaces over. Had she read her thoughts?

\subsection{Jeannine}

Eager to begin her new school year, Jeannine arrived early in the morning. There was only one car in the staff parking lot when she pulled in. It happened to be Mr. Donaldson's car and he was waiting at the front door to welcome her as she walked up the steps. After she had been in her new classroom for about an hour setting up her learning space, she heard a shuffle of footsteps down the hallway. Checking the time, she noticed it was five minutes before the start to the first staff meeting of her new school. She was just going to finish stapling the frame of her "All about Us and Our Community" wall. Jeannine was excited, eager, and ready for her first full year at UES. Having graduated from her professional program of teacher education a few years ago, Jeannine had had an opportunity to work as a substitute teacher at UES over the past two years. Last year, she had taken a part-time position at a school in a more rural and less diverse area twenty kilometres north of UES. She had loved working at UES and had made professional connections with some of the teachers and the principal during her substitute work. She had hoped that she would have gotten a contract there the year before, but being a new teacher, she jumped at the first opportunity. Over the course of the last year, she had reconnected with Thomas Donaldson and joined some of his professional learning days focused on creating a school community. She knew the challenges that the kids faced growing up in the heart of this city, and understood how their lives outside of school directly influenced their school experiences. Jeannine felt that to be a change-maker you needed to involve yourself in the communities that underwent the most disruptions. From her conversations with Mr. Donaldson and some of the Urbana Elementary teachers she had learned that the difficulties UES students face could be reduced, but that it would take a significant level of self-commitment and dedication. Something Mr. Donaldson had told her in the past informed her beliefs about labels, disability identification, and the true tenets of inclusive thinking and teaching: to really know if a student has a learning problem, we have to ensure that their social and emotional needs are being met first. Jeannine understood she was still new and naïve and that she had a lot to learn. She believed she was in the right environment to nourish her personal and professional growth. She stapled the last frame to her "All about Us and Our Community' wall, put the stapler on her couch in her Relax and Read corner, and enthusiastically turned towards the library where she was eager to meet her new colleagues and reconnect with others.

\section{MOVING TOWARDS THE MEETING :}

Thomas Donaldson always took the beginning of the year as a positive challenge. His belief in meeting the needs of the whole child grounded his approach in how he worked with (and supported) his teachers. The diversity and challenges that his students faced helped him navigate the challenges he seemingly always faced in getting some teachers to "buy in" to his inclusive leadership and teaching philosophy. Those teachers that bought into his approach to schooling were also a challenge because accepting diverse learning and attachment needs did not translate immediately into improved or inclusive practices. He also recognized that another factor was the time it took to be able to shift practices in the classroom, to change attitudes, and to accept that some students were going to need more help from their teachers to find safety and joy at school. Also, he knew that this shift would take commitment to collaboratively engage in the change process. The complexity of the teaching body 
was always difficult to navigate, in any case, and Mr. Donaldson knew that in each staff in any year, there would always be doubters. He also realized that some teachers presented set, inflexible beliefs about what school and the role of the teacher should look like. He was lucky to have his core group that he could turn to and partner with his newer teachers. The community of the school had changed in his seven years at UES; each year, a little for the better. Change was inevitable and improvement was always in the works. These school meetings were key for him in getting the year off to a good start and allowed him to design his plan in how he would match teachers, set individual goals with teachers, and generate discussion about professional learning opportunities throughout the year. Seated together in their first team semi-circle of the year, some eyes expressed anticipation, others looked a little sleep-deprived, others cast down their eyes at their pens scribbling notes or tapping the keys of their laptops, and some were clearly shaking off summer memories. Mr. Donaldson smiled and got ready to welcome everyone aboard.

\section{TEACHING NOTES :}

This case provides multiple insights for those who are principals or who are preparing for this role. It specifically addresses issues of attachment, teacher efficacy, and inclusion. Participants in leadership courses where this case is being used should have an essential understanding of each one of these concepts.

First, attachment theory posits that individuals need strong emotional or physical connections for healthy development (Holmes, 2014 [8]). The principal in this case, Mr. Thomas Donaldson, believes that the teachers in the school can support the development of children in the school through caring, nurturing relationships. He believes that the children in the school may not be developing strong and/or healthy attachments in other areas of their lives and that the school provides an important place for this to happen. Teachers can have a significant influence on the formation of relationships with students, thus fostering healthy emotional responses by students in schools (Riley, 2010 [9]). Principals can take an active role in encouraging healthy relationship-forming between teachers and students through modelling and by providing support for teachers.

Second, teacher efficacy is a teacher's self-assessment of abilities to help students attain a certain level of performance (Dixon et al., 2014 [10]). When teachers believe that they can make a difference in supporting students' learning outcomes, there is a greater potential that this will indeed occur. Collective teacher efficacy is when a group of teachers share the belief that through their collective action, they can positively influence student outcomes, including those who are disengaged or disadvantaged (Donohoo, 2017 [11]). An important note for principals who have many new teachers on staff-- such as Thomas Donaldson-- is to consider the notion of "professional efficacy discrepancy" (Friedman, 2000 [12]). Professional efficacy discrepancy refers to a discrepancy created when new teachers know that they should engage school principals in getting support but struggle to approach the principal to get that support. Collective teacher efficacy still provides a powerful opportunity to impact student learning outcomes. However, if newer teachers believe that they cannot, or should not, get support from principals or fellow teachers, it can prevent them from accessing the benefits of colleagues and professional communities. Thomas Donaldson needs to be aware of his role in creating the conditions that encourage new teachers to seek support and, as a result, fully contribute to, and access, collective teacher efficacy.

Third, this case raises issues of how principals support the inclusion of all students, including those from marginalized communities such as those with special education needs or from economically disadvantaged families. Schools are becoming increasingly diverse and this requires new competencies for principals (Theoharis\&Scanlan, 2015 [13]). Supporting inclusive schools can be particularly challenging for new principals (Northfield, 2013 [14]). However, even experienced principals experience challenging circumstances that cause them to re-examine their own core beliefs in supporting all students in schools. Principals such as Thomas Donaldson, who have significant professional experience, need to draw on these experiences and deeply held beliefs to foster inclusive school environments in which all students are valued and seen as contributing members. 


\section{CONCLUSION :}

Principals have significant opportunities to influence the school environment. However, this ability is tempered by the alignment of teachers' values and beliefs with those of the principal. In this case, Mr. Thomas Donaldson exhibits a strong desire to foster a healthy school environment where all students feel a sense of belonging. He believes that the foundation to this sense of belonging is the attachment that students and teachers develop. His challenge is to increase the teaching staff's individual and collective teaching efficacy so that they engage in the community, truly believing that they can support every child. Inclusive schools are those where every student believes that they belong. Principals such as Mr. Donaldson, and caring teachers, are partners in ensuring that inclusive schools are not just visionary aspirations but attainable goals.

\section{DISCUSSION QUESTIONS :}

1. What challenges do you anticipate Thomas Donaldson will experience in the staff meeting? If you were the principal, how would you proactively prepare yourself for these potential challenges?

2. Thomas Donaldson, "sees student's social emotional and academic success rooted in a healthy attachment to school in their early years of schooling." In what ways can principals foster inclusive schools that promote healthy attachment? Support your comments with examples.

3. Consider how this case is presented. Are there voices that are not present? Are certain perspectives more strongly presented and/or accepted? How might you aim for a balanced perspective when considering the different voices and perspectives? In what way can or should students' and parents, guardians, or caregivers' voices impact the work of principals and teachers?

4. Quietly reflect on your own leadership values and beliefs:

- What do I believe about inclusion?

- Who am I here to serve?

- Why do I lead in the way that I do?

- How might I learn from the experiences and insights of others?

\section{CLASS ACTIVITIES AND RESOURCES :}

1. Read this blog from the University of Portland; particularly, the section on what leaders can do to foster teacher efficacy:https://education.cu-portland.edu/blog/curriculum-teaching-strategies/improveteacher-efficacy/. Engage in a think-pair-share (think quietly for a minute, pair up with another person, share your responses) about how you could support the teacher efficacy (either individual or collective) of teachers.

2. Role play in groups of four in the following situation: Thomas has just completed the opening session with the teachers. He sat down with Jennifer, Emily, and Jeannine to discuss how they can work collectively to support all of the students in their classes. Role play what you would do if you were Thomas. One person each should role-play Thomas, Jeannine, Emily, and Jennifer.

3. In small groups, use chart paper to map out the steps you would take over the next nine months as the principal to support collective teacher efficacy in Urbana Elementary. Share your planning with others in the course.

4. Two well-known writers on collective teacher efficacy are John Hattie and Jennifer Donohoo. Divide the class into two sections. One section examines Hattie's influences on student achievement (https://us.corwin.com/sites/default/files/250_influences_10.1.2018.pdf) and the other examines Donohoo's "six enabling conditions" (https://thelearningexchange.ca/collective-teacher-efficacy/). After 30 minutes, return together and share three key learnings that were experienced by examining the resources.

5. As a class, watch this 10 minute video with John Hattie (https://www.youtube.com/watch?v=UCMV692itfg). As a class, discuss what Hattie means by social sensitivity. Using a Google Doc or chart paper, identify ways in which school principals can support teachers' social sensitivity. 


\section{REFERENCES :}

[1] Hackney, R., McMaster, T., \& Harris, A. (2003). Using cases as a teaching tool in IS education. Journal of Information Systems Education, 14(3), 229-234.

[2] Watson, C. (2014). Effective professional learning communities? The possibilities for teachers as agents of change in schools. British Educational Research Journal, 40(1), 18-29.

[3] Griffin, D. \& Ryan, J. (Eds.). Case studies for inclusive educators and leaders. Burlington, ON: Word and Deed Publishing.

[4] Gardiner, M. E., \& Tenuto, P. L. (2015). Reflections of practicing school principals on ethical leadership and decision-making: Confronting social injustice. The Journal of Values-Based Leadership, 8(2), Retrieved from: https://scholar.valpo.edu/cgi/viewcontent.cgi?article=1127\&context=jvbl.

[5] Hanhimäki, E., \&Tirri, K. (2009). Education for ethically sensitive teaching in critical incidents at school. Journal of Education for Teaching, 35(2), 107-121.

[6] Mezirow, J. \& Taylor, E. W. (2009). Transformative learning theory. In Mezirow, J. \& Taylor, E. W. (Eds.). (2009). Transformative learning in practice: Insights from community, workplace, and higher education (pp. 18-31). San Francisco, CA: John Wiley \& Sons.

[7] Yamamoto, J. K., Gardiner, M. E., \& Tenuto, P. L. (2014). Emotion in leadership: Secondary school administrators' perceptions of critical incidents. Educational Management Administration \& Leadership, 42(2), 165-183.

[8] Holmes, J. (2014). John Bowlby and attachment theory. New York, NY: Routledge.

[9] Riley, P. (2010). Attachment theory and the teacher-student relationship: A practical guide for teachers, teacher educators and school leaders. New York, NY: Routledge.

[10] Dixon, F. A., Yssel, N., McConnell, J. M., \& Hardin, T. (2014). Differentiated instruction, professional development, and teacher efficacy. Journal for the Education of the Gifted, 37(2), 111127.

[11] Donahoo, J. (2017). Collective teacher efficacy: The effect size research and six enabling conditions. The Learning Exchange. Retrieved from: https://thelearningexchange.ca/ collective-teacher-efficacy/

[12] Friedman, I. A. (2000). Burnout in teachers: Shattered dreams of impeccable professional performance. Journal of Clinical Psychology, 56(5), 595-606.

[13] Theoharis, G., \&Scanlan, M. (2015). Inclusive leadership for increasingly diverse schools. In textbook series Educational leadership for equity and diversity. New York, NY: Routledge.

[14] Northfield, S. (2013). The novice principal: Change and challenges. Canadian Journal of Educational Administration and Policy, 142, 158-182. 